\title{
Effects of corn cob ash on lime stabilized lateritic soil
}

\author{
Emeka Segun Nnochiri \\ Afe Babalola University, Ado Ekiti, Nigeria \\ Department of Civil and Environmental Engineering \\ e-mail: segunemeka@yahoo.com
}

\begin{abstract}
This study assesses the effects of Corn Cob Ash (CCA) on lime-stabilized lateritic soil. Preliminary tests were carried out on the natural soil sample for purpose of identification and classification. Lime being the main stabilizing material was thoroughly mixed with the soil sample to determine the optimum lime requirement of the sample as a basis for evaluating the effects of the CCA. The optimum lime requirement was 10\%. The CCA was thereafter added to the lime stabilized soil in varying proportions of 2, 4, 6, 8 and $10 \%$. Unsoaked CBR increased from $83 \%$ at $0 \%$ CCA to highest value of $94 \%$ at $4 \%$ CCA. Unconfined Compressive Strength (UCS) values increased from $1123 \mathrm{kN} / \mathrm{m}^{2}$ at $0 \%$ CCA to highest value of $1180 \mathrm{kN} / \mathrm{m}^{2}$ at $4 \%$ CCA. It was therefore concluded that CCA can serve as a good complement for lime stabilization in lateritic soil.
\end{abstract}

Key words: atterberg limit, corn cob ash, lateritic soil, lime stabilization, strength tests

\section{Introduction}

According to Joel and Edeh [1], the importance of road in the development of any nation can hardly be over-emphasized, as it plays a strategically important role in the transportation of good and services. This is commonly achieved through the vast network of roads that connect the rural and urban centers. Efforts at achieving the construction of more roads is hindered by the high cost of building new roads, which is attributable to non-availability of sound quality road building materials within the environment of many road project. Lateritic soil, being a sedimentary rock deposit and a product from the weathering of rocks, is one of the most common, ubiquitous and readily available road building materials that can be sourced locally in Nigeria.

It has been found that lateritic soils are generally good construction materials and are therefore commonly used in construction. In the tropical part of the world, as Nigeria is, lateritic soils are used as a road making material and they constitute the sub-grade of most tropical roads, they are used as sub base and bases for low cost roads and these carry low to 
medium traffic. The word 'laterites' describes no material with reasonably constant properties; it can denote a different material to people living in different parts of the world [2]. This study identifies with the definition as posited by Ola [3], as product of tropical weathering with red, reddish brown and dark brown colour, with or without nodules or concreting and generally (but not exclusively) found below hardened ferruginous crust or hard pan. Most lateritic soils in their natural states have low bearing capacity and low strength due to high content of clay. In an event that lateritic soil contains a high amount of clay materials its strength and stability cannot be guaranteed under load especially in the presence of moisture. When lateritic soil consists of high plastic clay, the plasticity of the soil is capable of causing cracks and damage on pavement, road ways, building foundations or any other civil engineering construction projects. The improvement in the strength and durability of lateritic soil in recent time has become imperative; this has led researchers toward using stabilizing materials that can be sourced locally at a very low cost. These local materials can be classified as either agricultural or industrial wastes [4].

Furthermore, locally sourced materials are fast gaining prominence because the over dependent on the utilization of industrially manufactured soil improving additives - cement, lime etc have kept the cost of construction of stabilized road financially high [5] and also, about $7 \%$ of $\mathrm{CO}_{2}$ released into the atmosphere is normally during the process of cement production, which is responsible for global warming [6]. In line with the foregoing, replacing proportions of the Portland cement in Soil Stabilization with agricultural wastes material like Corn Cob Ash will go a long way in mitigating the harsh effects of increased Portland cement production and costs.

\subsection{Corn Cob Ash}

Corn Cob is the hard thick cylindrical central core of the Corn (on which are borne the grains or kernels of an ear of corn). Corn Cob is an agricultural waste product obtained from corn, which is reputed to be most important cereal crop is Sub-Sahara Africa. 589 million tons of maize were produced worldwide in the year 2000. The United States was the largest maize producer having $43 \%$ of world production. Africa produced $7 \%$ of the maize. Nigeria was the second largest producer of maize in Africa in the year 2001 with 4.62 million tons. South Africa had the highest production of 8.04 million tons [7].

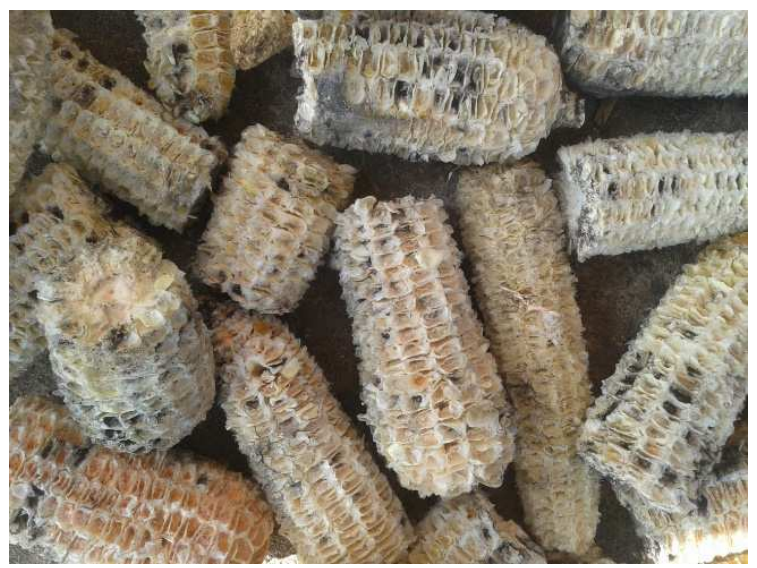

Figure 1: Pieces of corn cob 


\subsection{Lime Stabilization}

Lime provides an economical way of soil stabilization. Lime modification describes an increase in strength brought about by cation exchange capacity rather than cementing effect brought about by pozzolanic reaction. Lime Stabilization may refer to pozzolanic reaction in which pozzolanic materials react with the lime in presence of water to produce cementitious compounds [8].

Lime-Soil chemical reaction has two stages. The first stage which is known as immediate or short-term treatment, occurs within a few hours or days after lime is added. Three main chemical reactions namely; cationic exchange, flocculation-agglomeration and carbonation occur at this stage. The second stage requires several months or years to complete and it is considered the long-term treatment. Pozzolanic reaction is the main reaction at this stage [9].

\section{Materials and Methods}

\subsection{Materials}

The materials used were: lateritic soil, corn cob ash, hydrated lime and potable water. The lateritic soil sample was obtained from a borrow pit located in Federal University of Technology, Akure, Nigeria at depths between $1.2 \mathrm{~m}$ and $1.5 \mathrm{~m}$. Hydrated lime was bought at an accredited chemical store. Corn cob was obtained from the corn vendor, dried in the sun to eliminate moisture and burnt in an open drum to obtain the corn cob ash, which is later ground and sieved through sieve $75 \mu \mathrm{m}$. Potable water was obtained from the Geotechnical Laboratory of the Federal University of Technology, Akure.

\subsection{Methods}

Preliminary tests (such as natural moisture content, specific gravity, particle size analysis and Atterberg limits test) were carried out on the natural lateritic soil sample for the purpose of determining its index properties. Hydrated lime which was the main stabilizing material was then thoroughly mixed with the soil sample so as to determine the optimum lime requirement of the sample. These properties were adopted as a standard for evaluating the effects of CCA on the lime - Stabilized Samples. The CCA was added to the lime-treated lateritic soil in varying proportions of 2, 4, 6, 8 and $10 \%$ by weight of soil, thereafter, each of the mixes was subjected to the following tests; Atterberg limits, unconfined compressive strength (UCS), California bearing ratio (CBR) and compaction.

\subsubsection{Atterberg limits test}

The Atterberg limits tests were carried out in accordance with the British Standard MethodsBS 1377 [10]. The lateritic soil sample was sieved through $0.425 \mathrm{~mm}$. Materials that were retained on the sieve was discarded and not used for the test. The soil sample was oven-dried for at least 2 hours before the test. For the stabilized specimens; the tests were carried out on the soils mixed with lime alone and on soils with the fixed optimal amount of required lime and varying proportions of 2, 4, 6, 8 and $10 \%$ CCA. 


\subsubsection{Compaction Characteristics}

The proctor standard compaction method was adopted for this study. The test was carried out according to BS 1377 [10], with the purpose of determining the maximum dry density (MDD) and the optimum moisture content (OMC) of the soils. The soil mixtures (with or without additives) were thoroughly mixed with various moisture content and allowed to equilibrate for 24 hours before compaction. The first aspect of the compaction test involved determining the compaction properties of the natural soil sample. At the second stage, tests were performed to determine the proctor compaction properties of soil sample upon stabilization with lime at optimal amount required and the varying amount of CCA $(2,4,6,8$ and 10\%).

\subsubsection{California bearing ratio (CBR)}

The BS 1924 [11] stipulates the procedures to follow in carrying out this test. This, was however modified in conformity with the recommendation of the Nigerian General Specification, Federal Ministry of Works and Housing [12], which stipulates that specimens be cured for six days unsoaked, immersed in water for 24 hours and allowed to drain for 15 minutes before testing.

\subsubsection{Unconfined Compressive Strength (UCS)}

The BS 1924 [11] stipulates the procedure for carrying out this test and was adopted for the natural soil sample. For the stabilized soil mixtures, specimen were prepared by carefully and completely mixing dry quantities of pulverized soil with the fixed optimal amount of hydrated lime required and varying proportions of 2, 4, 6, 8 and 10\% CCA. The needed amount of water was determined from moisture-density relationships for stabilized-soil mixtures was subsequently added to the mixture. For each of the mix, three specimens were prepared as stipulated by the Nigerian General Specification, Federal Ministry of Works and Housing [12].

\section{Results and Discussion}

Table 1: The chemical compositions by weight percentage of Corn Cob Ash [13] and hydrated lime used for this research.

\begin{tabular}{|l|l|l|}
\hline Elemental Oxides & CCA (Weight \%) & Hydrated lime (Weight \%) \\
\hline $\mathrm{CaO}$ & 10.24 & 68.12 \\
\hline $\mathrm{SiO}_{2}$ & 64.90 & 1.71 \\
\hline $\mathrm{MgO}$ & 2.08 & 1.38 \\
\hline $\mathrm{Na}_{2} \mathrm{O}$ & 0.43 & 0.03 \\
\hline $\mathrm{Al}_{2} \mathrm{O}_{3}$ & 10.79 & 0.72 \\
\hline $\mathrm{Fe}_{2} \mathrm{O}_{3}$ & 4.75 & 0.05 \\
\hline $\mathrm{SO}_{3}$ & 2.53 & 0.04 \\
\hline $\mathrm{K}_{2} \mathrm{O}$ & 4.23 & 0.06 \\
\hline
\end{tabular}


From the table 1, the total sum by weight percentage composition of $\mathrm{SiO}_{2}, \mathrm{Al}_{2} \mathrm{O}_{3}$ and $\mathrm{Fe}_{2} \mathrm{O}_{3}$, which is $64.90 \%, 10.79 \%$ and $4.75 \%$ equal $80.44 \%$ which is greater than the required minimum value of $70 \%$ for the stabilizing agent to pass for pozzolanic material [14].

Pozzolan is described as a siliceous or silicious and aluminous material which in itself possesses little or no cementitious value but will, in finely divided form and in the presence of moisture, chemically reacts with calcium hydroxide at ordinary temperatures to form compounds possessing cementitious properties [15].

Table 2: Summary of geotechnical properties of soil sample

\begin{tabular}{|l|c|}
\hline Property & Amount \\
\hline Percentage passing BS Sieve No 200 (\%) & 4.2 \\
\hline Liquid Limit (LL) (\%) & 37 \\
\hline Plastic Limit (PL) (\%) & 21 \\
\hline Plasticity Index (PI) (\%) & 16 \\
\hline AASHTO Classification & $\mathrm{GP}$ \\
\hline USCS Classification & 1998 \\
\hline Maximum Dry Density (MDD) $\left(\mathrm{Kg} / \mathrm{m}^{3}\right)$ & 13.2 \\
\hline Optimum Moisture Content (OMC) (\%) & 550 \\
\hline $\begin{array}{l}\text { Unconfined Compressive Strength (UCS) } \\
\text { (kN /m }{ }^{2} \text { ) }\end{array}$ & 26 \\
\hline CBR (Unsoaked) (\%) & 12 \\
\hline CBR (Soaked) (\%) & 2.67 \\
\hline Specific gravity & 8.6 \\
\hline Natural Moisture Content (\%) & \\
\hline
\end{tabular}

Preliminary Test: From table 2, the specific gravity of the natural lateritic soil sample is 2.67. Most clay minerals have specific gravity within the range of $1.6-2.9$ for them to be suitably qualified to be considered as halloysites. Based on the foregoing, the soil sample is halloysite [16]. The natural lateritic soil sample is of intermediate plasticity, this is based on Whitlow classification of material with liquid limit less than $35 \%$ being indicative of low plasticity, between $35 \%$ and $50 \%$ and between $51 \%$ and $70 \%$ being indicative of intermediate and high plasticity respectively, while values greater than $70 \%$ is indicative of very high plasticity [1].

Using the AASHTO soil classification system, the soil was classified into the A-2 group, since less than $35 \%$ granular materials passed through Sieve No 200. The liquid limit value (37\%) does not exceed the maximum value of $40 \%$ while the Plasticity Index value $(16 \%)$ exceeds the minimum value of $11 \%$ [17]. 


\section{Compaction Characteristics:}

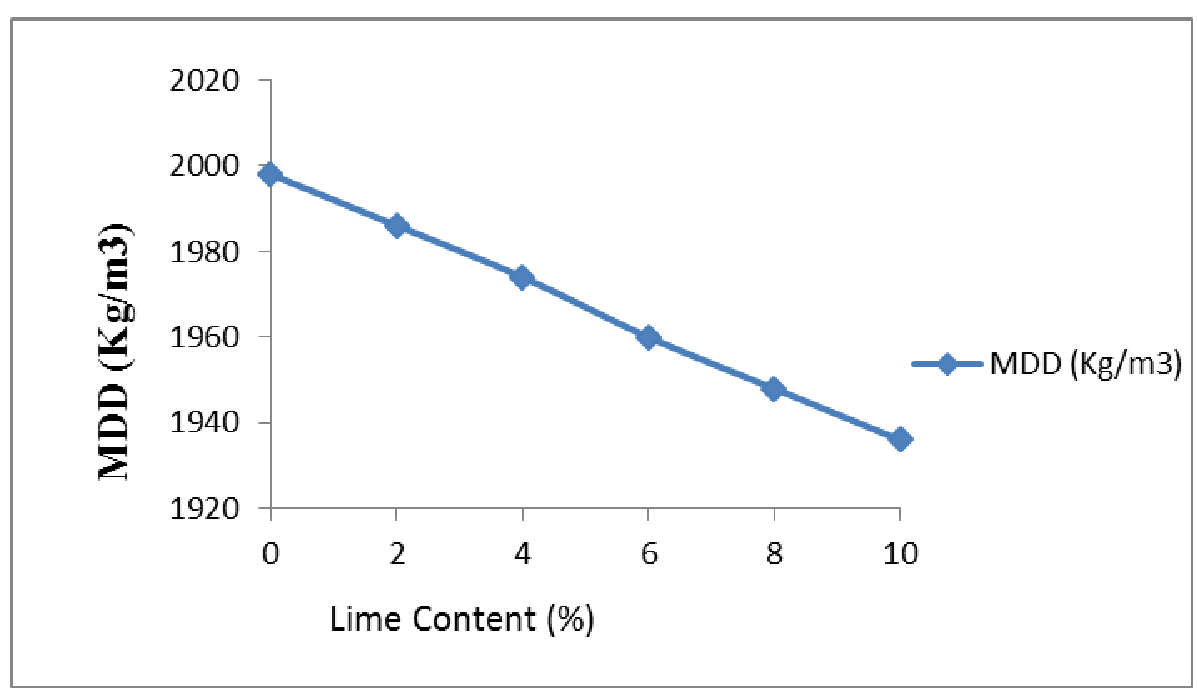

Figure 2: Effect of lime on MDD of lateritic soil.

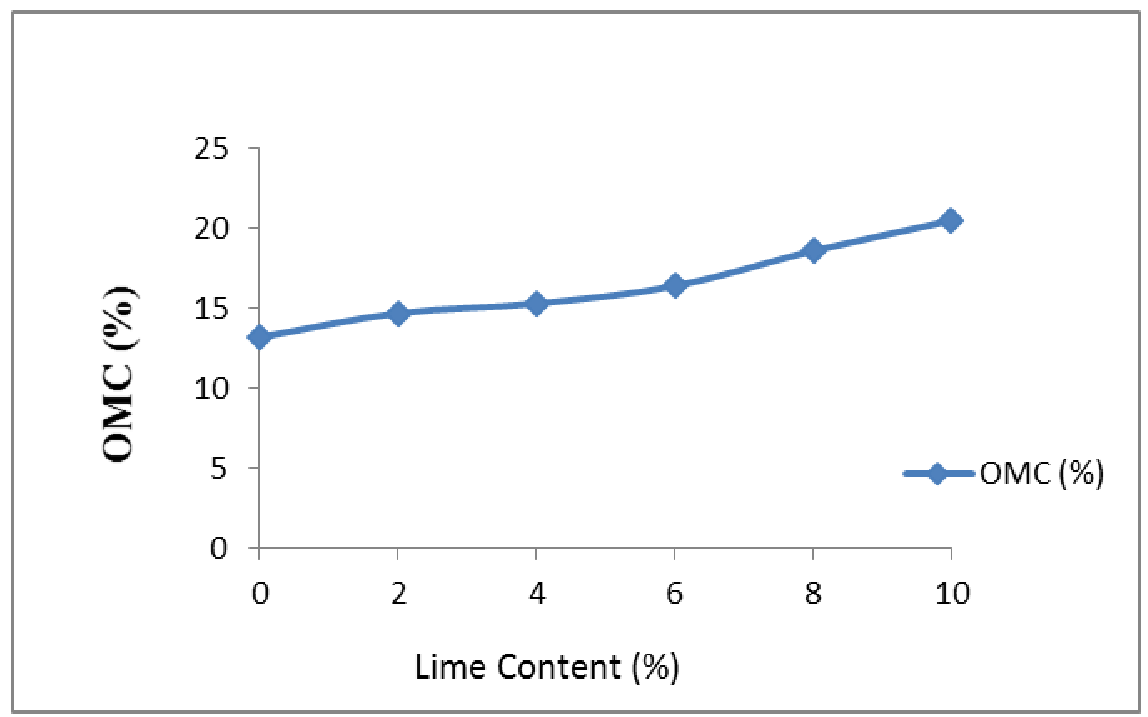

Figure 3: Effect of lime on OMC of lateritic soil. 


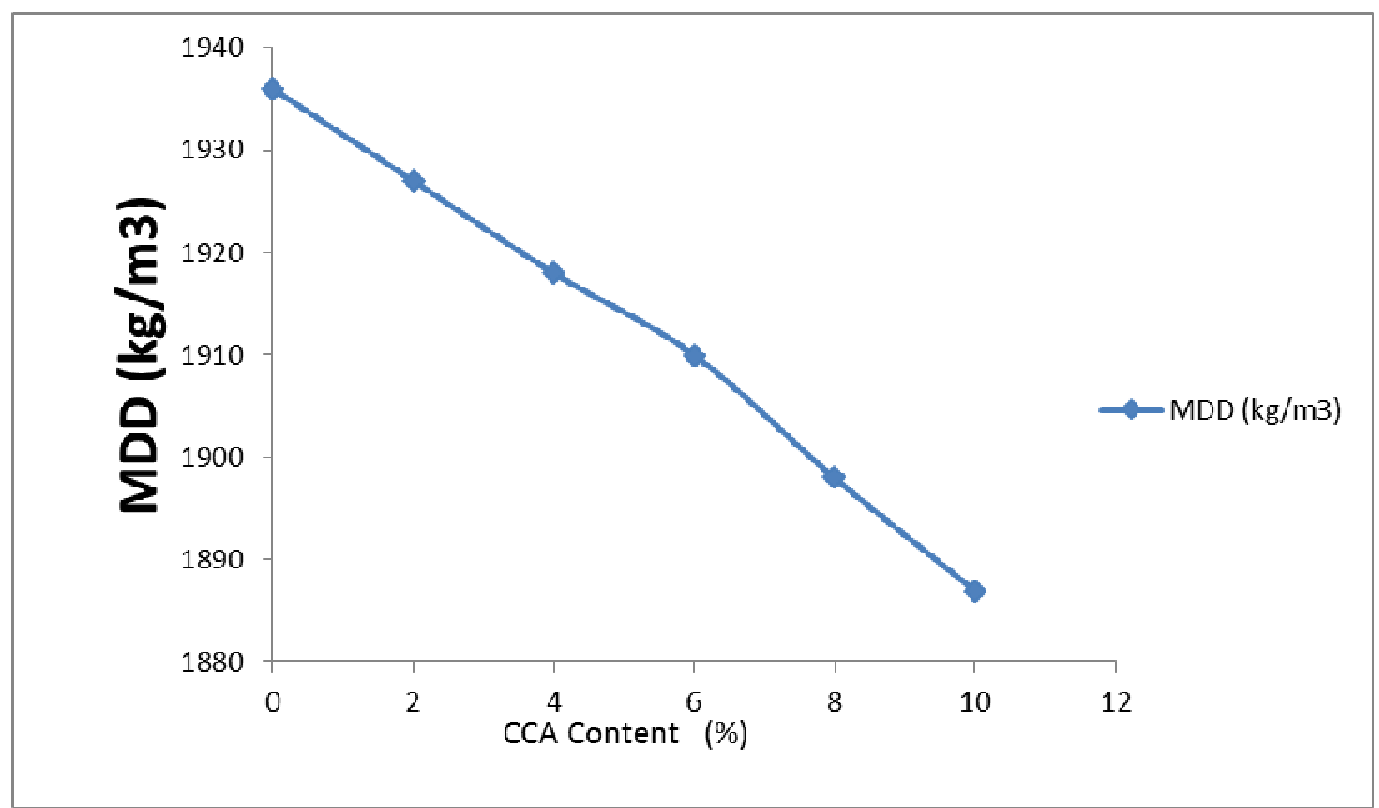

Figure 4: Effect of CCA on MDD of lime-treated lateritic soil.

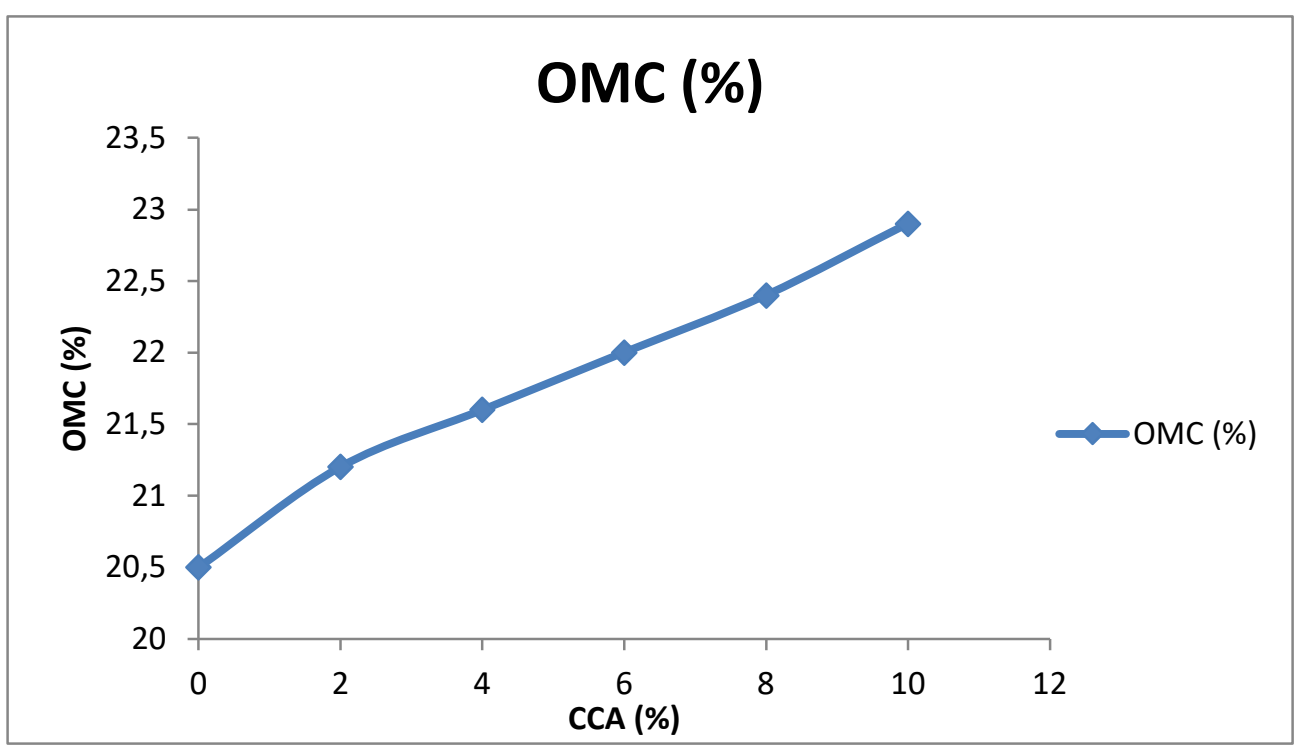

Figure 5: Effect of CCA on OMC of lime-treated lateritic soil

Figure 2 shows that there was a general decrease in values of Maximum Dry Density (MDD) with increasing addition of lime content, also, figure 3 shows a trend of general increase in values of Optimum Moisture Content (OMC) as increased percentages of lime was being added, according to Zoubir et al., [18], this behavior may be attributed to the following reasons: the lime causes aggregation of the particle to occupy larger spaces and hence alters the effective grading of the soil. The specific gravity of lime (2.24) is lower than the specific gravity of soils (2.67) tested. The pozzolanic reaction between the clay present in the lateritic soil and lime is responsible for the increase in OMC. Furthermore, increase in OMC is due to the high surface area of lime and the decrease in MDD is due to the low specific gravity of lime. Also, figures 4 and 5 show the effects of CCA on Maximum Dry Density (MDD) and 
Optimum Moisture Content (OMC) of the lime-treated lateritic soil respectively. There were trends of general decrease in MDD and increase in values of OMC. The increase in values of OMC with increase in percentage of Corn cob ash (CCA) could be attributed to the increased amount of water required in the system to adequately lubricate all the particles in the soil-lime and CCA mixture. Therefore, the optimum moisture content continuously increased with increase in CCA content, while the decrease in values of MDD as an effect of CCA on the soil-lime mixture could be due to the partial replacement of the soil with higher specific gravity (2.67) by CCA with lower specific gravity of 2.50 . Also, it can be viewed from the angle of the reaction between lime, CCA and fine fractions of the soil in which they form clusters that occupied larger spaces and thereby increasing their volume with decreasing the maximum dry density [19].

\section{Unconfined Compressive Strength (UCS):}

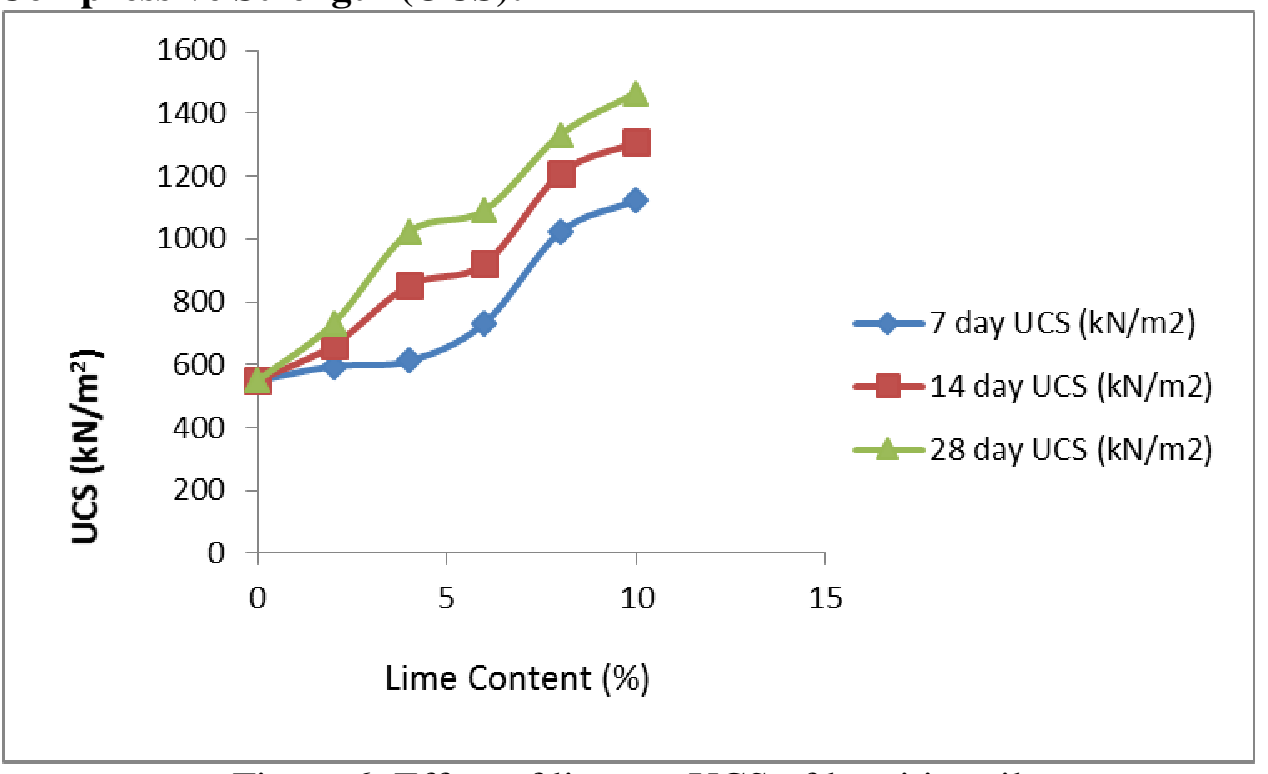

Figure 6: Effect of lime on UCS of lateritic soil

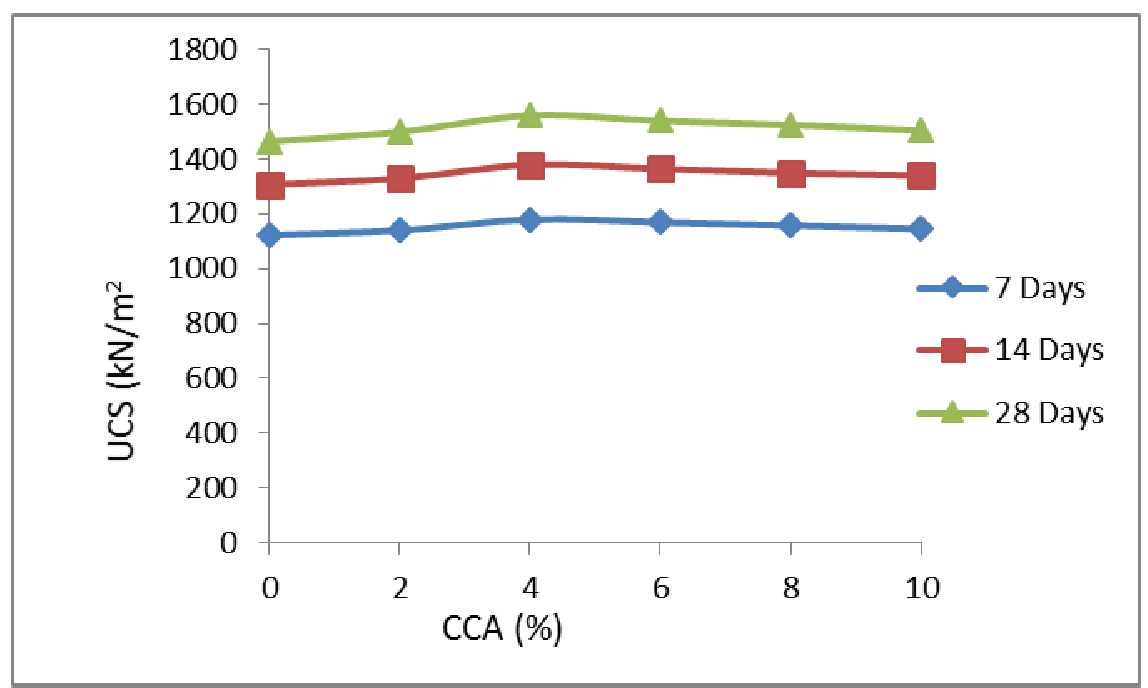

Figure 7: Effect of CCA on UCS of lime-treated lateritic soil 
Figures 6 and 7 show the effect of lime on unconfined compressive strength of lateritic soil and the effect of Corn cob ash (CCA) on unconfined compressive strength of lime-treated lateritic soil. Figure 6 shows general increase in values of unconfined compressive strength from $550 \mathrm{kN} / \mathrm{m}^{2}$ at $0 \%$ lime to $1123 \mathrm{kN} / \mathrm{m}^{2}$ at $10 \%$ lime for a period of 7 days curing. Increase in UCS may be attributed to lateritic soil-lime reaction which results to the formation of cementitious compounds that binds lateritic soil together [20]. With the addition of CCA to the lime-treated soil, the value of the unconfined compressive strength increased from $1123 \mathrm{kN} / \mathrm{m}^{2}$ at $0 \% \mathrm{CCA}$ to highest value of $1180 \mathrm{kN} / \mathrm{m}^{2}$ at $4 \% \mathrm{CCA}$, at this value $\left(1180 \mathrm{kN} / \mathrm{m}^{2}\right)$, the requirement for sub base of road works has been met, since the requirement for sub base is $750 \mathrm{kN} / \mathrm{m}^{2}-1500 \mathrm{kN} / \mathrm{m}^{2}$ for 7-day curing [19].

\section{California Bearing Ratio:}

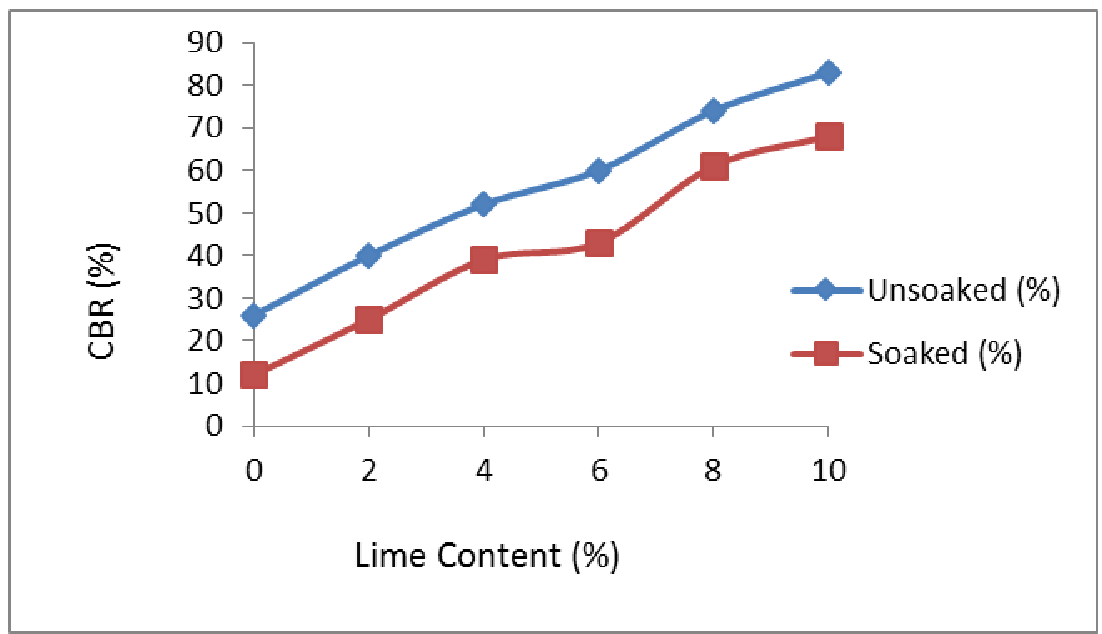

Figure 8: Effect of Lime on CBR of lateritic soil

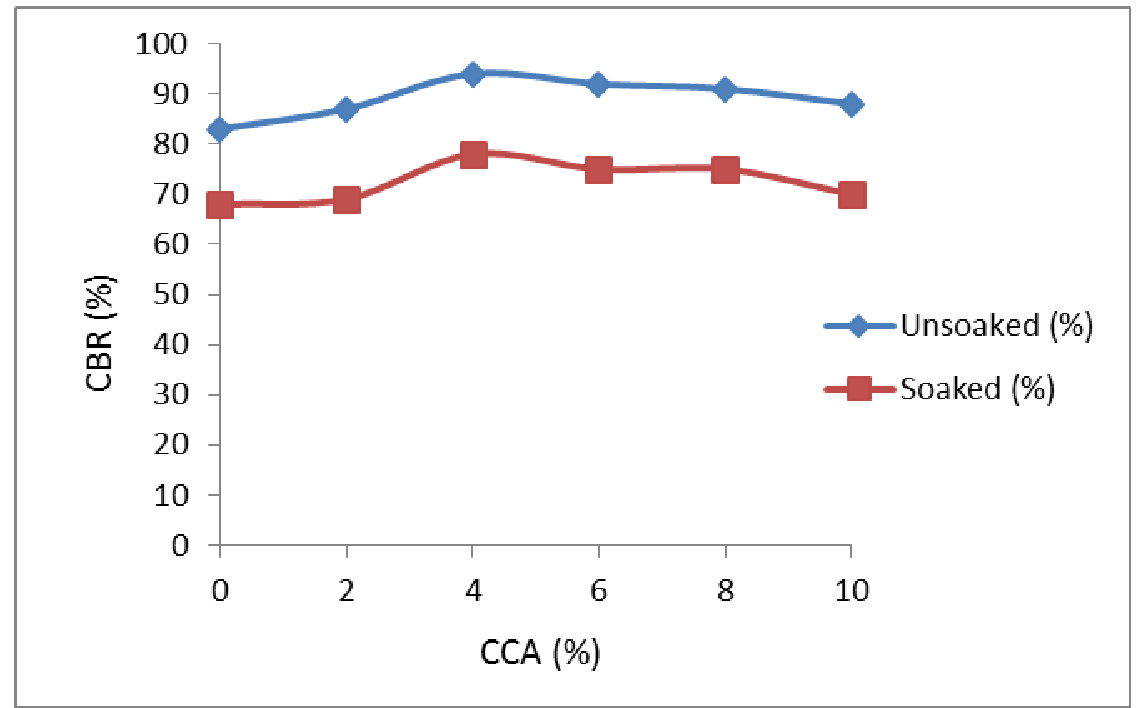

Figure 9: Effects of CCA on CBR of lime-treated lateritic soil 
Figure 8 shows general increase in unsoaked and soaked CBR values with addition of higher proportion of lime. Unsoaked CBR rose from $26 \%$ at $0 \%$ lime to $83 \%$ at $10 \%$ lime, while soaked CBR rose from $12 \%$ at $0 \%$ lime to $68 \%$ at $10 \%$ lime. Such increase may be due to the gradual formation of cementitious compounds in the soil by the reaction between the lateritic soil and lime [20]. Values of Unsoaked CBR increased from $83 \%$ at $0 \%$ CCA to highest value of $94 \%$ at $4 \%$ CCA, while soaked CBR increased from $68 \%$ at $0 \%$ CCA to $78 \%$ at $4 \%$ CCA (Figure 9). According to the Federal Ministry of Works and Housing [12], specimens should be cured for six days unsoaked, immersed in water for 24 hours and allowed to drain for 15 minutes before testing, in addition to this, subgrade or fill material is expected to have a liquid limit value of less than $50 \%$ and plasticity index should be equal or less than $30 \%$, while for sub base, liquid limit is expected to be equal or less than $30 \%$ and plasticity index should be equal or less than $12 \%$. Furthermore, for subgrade material, the soaked CBR should be equal or less than $10 \%$. Soaked CBR for subbase should be equal to or more than $30 \%$. Unsoaked CBR value for base course should be equal to or more than $80 \%$. From the foregoing, the value- $94 \%$ for unsoaked CBR at $4 \%$ CCA and all soaked CBR values at their respective CCA contents are fit for use in stabilizing soil for use as base and sub base courses.

\section{Atterberg limits:}

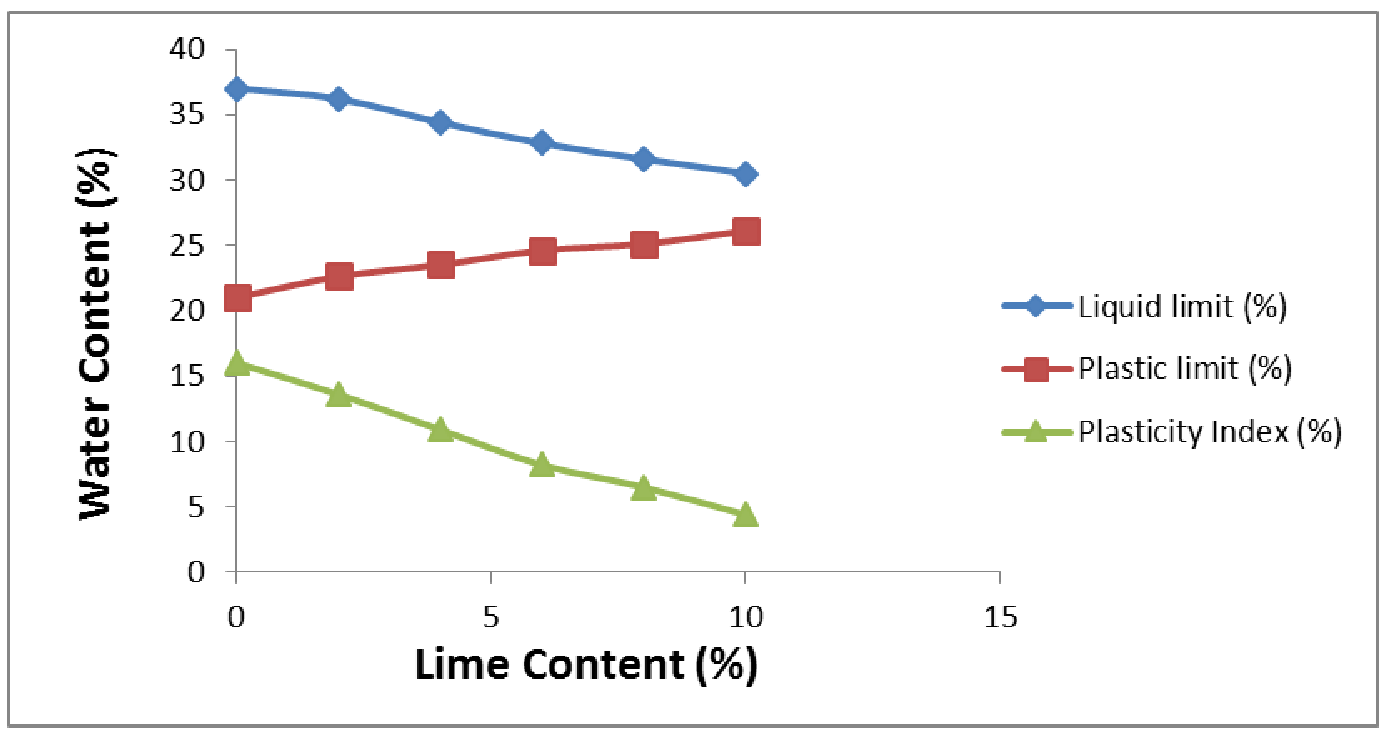

Figure 10: Effect of Lime on CBR of lateritic soil 


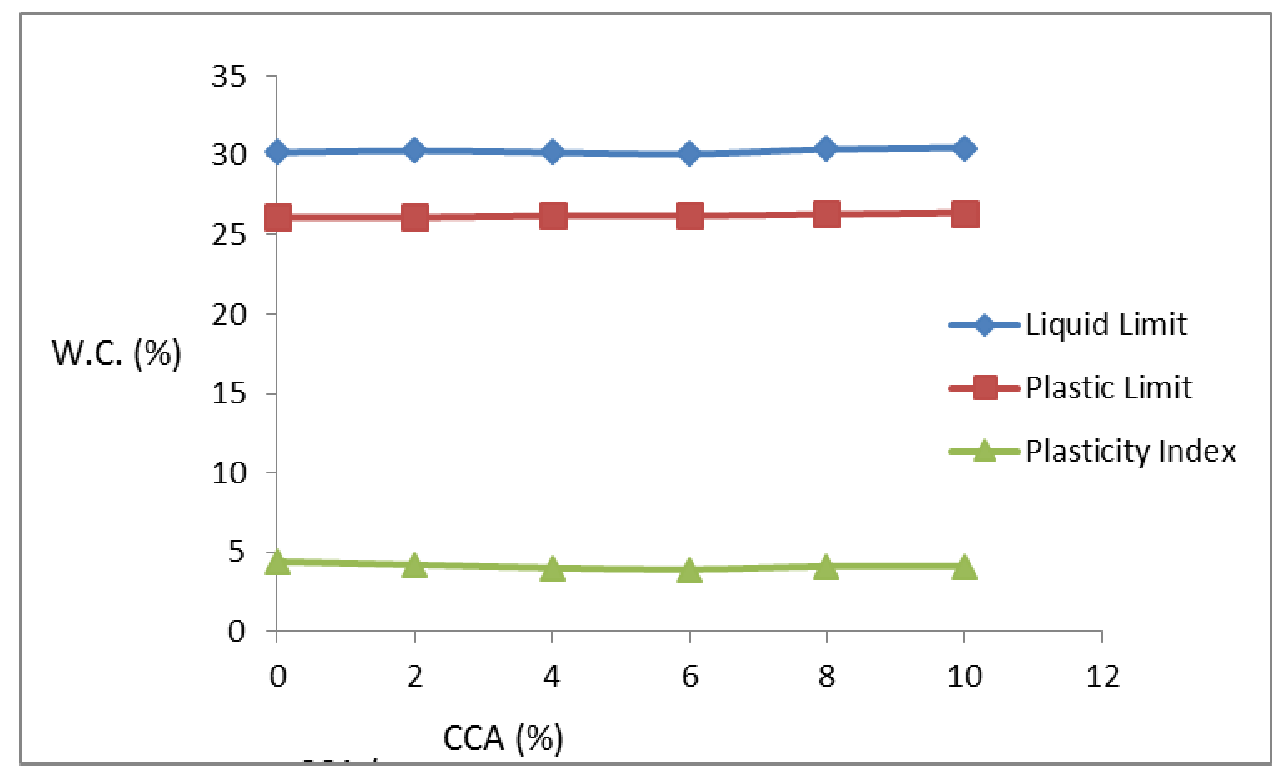

Figure 11: Effect of CCA on Atterberg Limits of lime-stabilized lateritic soil

Figure 10 shows that the lime reduced the liquid limit (LL) value of the lateritic soil from $37 \%$ to $30.5 \%$ and plasticity index (PI) value from $16 \%$ to $4.4 \%$ both at $10 \%$ lime content (optimal lime requirement). Figure 11 shows effect of CCA on Atterberg limits of limetreated lateritic soil, there was a decrease from $30.5 \%$ at $0 \%$ CCA to the minimum value of $30.1 \%$ at $6 \% \mathrm{CCA}$, also plasticity index (PI) decreased from $4.4 \%$ at $0 \%$ CCA to $3.9 \%$ at $6 \%$ CCA. Decrease in values of liquid limit (LL) and plasticity limit (PI) can be attributed to the formation of cementitious compounds, hence improvement of the soil [20]. Soils with plasticity index higher than $12 \%$ are not suitable for use as sub base materials for roads in Nigeria [21].

\section{Conclusion}

From the results of the study, the following conclusions can be drawn;

The lateritic soil is classified as A-2-6 using AASHTO classification system and GP using the USCS.

The optimal amount of lime required is $10 \%$, because at $10 \%$ lime the least value of plasticity index was recorded. The addition of corn cob ash (CCA) further reduced the plasticity index value, thus, improving the soil properties.

The maximum dry density (MDD) and optimum dry density (OMC) of lime-treated soil decreased and increased respectively with the addition of the CCA.

Upon the addition of CCA to the lime-treated soil, the values of unsoaked and soaked CBR improved considerably.

The addition of CCA to the lime-treated soil improved the unconfined compressive strength (UCS) values to peak values at 4\% CCA. UCS values also increased with curing ages of 7,14 and 28 days.

Based on the results of this research, the corncob ash aptly qualifies as a pozzolanic material. Also, the CCA can serve as a good complement for lime stabilization in lateritic soils. 


\section{Acknowledgements}

The Author hereby wishes to use this medium to appreciate the geotechnical engineering laboratory teams of the departments of civil and environmental engineering of both Afe Babalola University, Ado Ekiti and Federal Uniersity of Technology, Akure, Nigeria for the support rendered while this work lasted.

\section{References}

[1] Joel, M. \& Edeh, J. E. (2015). Comparative Analysis of Cement and Lime Modification of Ikpayongo Laterite for Effective and Economic Stabilization. Journal of Emerging Trends in Engineering and Applied Sciences (JETEAS) 6 (1): 49-56.

[2] Amu O. O. \& Adetuberu, A.A. (2010). Characteristics of Bamboo Leaf Ash Stabilization on Lateritic Soil in Highway Construction. International Journal of Engineering and Technology. Vol. 2 (4), 2010, 212-219.

[3] Ola, S. A. (1983). Geotechnical properties and behavior of some Nigerian Lateritic Soils: In, S. A. Ola, (ed.), Tropical Soils of Nigeria in Engineering Practice, (pp 61-84) A. A. Balkana / Rotterdam: Netherlands.

[4] Bello, A. A., Ige, J. A. \& Ayodele, H. (2015). Stabilization of Lateritic Soil with Cassava Reels Ash. British Journal of Applied Science and Technology 7 (6): 642-650, 2015, Article No: BJAST. 2015. 180, ISSN: 2231-0843

[5] Ogunribido, T.H.T. (2011). Potentials of Sugar Cane Straw Ash for Lateritic Soil Stabilization in Road Construction. International Journal of Science Emerging Technology. Vol. 3, No 5, May 2011.

[6] Aribisala, O.A. (1989). Sourcing of Local Raw Materials and Investment Opportunity in Building / Construction Industrial Sector. National Workshop held at Calabar in 1989.

[7] Olafusi, O.S. \& Olutoge, F. A. (2012). Strength Properties of Corn Cob Ash Concrete. Journal of Emerging Trends in Engineering and Applied Sciences (JETEAS) 3(2): 297-301.

[8] Sherwood, P.1993. Soil Stabilization with Cement and Lime. State of the Art Review. London: Transport Research Laboratory, HMSO.

[9] Jawad, I. T., Taha, M. R., Majeed, Z. H. \& Khan, T. A. (2014). Soil Stabilization Using Lime; Advantages, Disadvantages and Proposing a Potential Alternative. Research Journal of Applied Sciences, Engineering and Technology. 8(4): 510-520.

[10] British Standards (BS) 1377. (1990). Methods of Tests for Soils for Civil Engineering Properties. London: British Standards Institution, London, U. K. 143.

[11] British Standards (BS) 1924. (1990). Methods of Test for Stabilized Soils. British Standards Institutions. London, U. K.

[12] Federal Ministry of Works \& Housing. (1997). General Specification for Roads and Bridges, Volume II, Federal Highway Department, FMWH: Lagos, Nigeria.

[13] Owolabi, T. A., Oladipo, I. O. \& Popoola, O. O. (2015). Effect of Corncob Ash as a Partial Substitute for Cement in Concrete. New York Science Journal 2015, 8 (11).

[14] ASTM C618. 1978. American Society for Testing and Materials, Specifications for pozzolans, ASTM International: West Conshohocken, PA, USA.

[15] Akinyele, J. O., Salim, R. W., Oikelome, K.O. \& Olateju, O. T. (2015). The Use of Rice Husk Ash as a Stabilizing Agent in Lateritic Clay Soil. International Journal of Civil, Environmental, Structural, Construction and Architectural Engineering. Vol. 9, No. 11.

[16] Amu, O. O. \& Babajide, S.S. (2011). Effects of Bamboo Leaf Ash on Lime Stabilized Lateritic Soil for Highway Construction. Research Journal of Applied Sciences, Engineering and Technology 3 (4): Pp 278-283, 2011. 
[17] Garber, N. J. \& Hoel, L. A. (2009). Traffic and Highway Engineering, $4^{\text {th }}$ Edition, CENGAGE Learning, U.S.A. Pp. 909.

[18] Zoubir, W., Harichane, K \& Ghria, M. (2013). Effect of Lime and Natural Pozzolana on Dredged and Fludge Engineering Properties. Electronic Journal of Geotechnical Engineering (EJGE), Vol. 18 (2013) Pp. 589.

[19] Okonkwo, U.N. (2015). Optimization of Baggase Ash content in Cement. Published Ph.D thesis, Department of Civil Engineering, University of Nigeria, Nsukka.

[20] Fattah, M.Y., Rahil, F.H. \& Al-Soudary, K.Y.H. (2013). Improvement of Clayey Soil Characteristics Using Rice Husk Ash. Journal of Civil Engineering and Urbanism, Vol. 3, Issue 1: 1218, 2013.

[21] Oyediran, A.I. \& Kalejaiye, M. (2011). Effect of Increasing Cement Content on Strength and Compaction Parameters of Some Lateritic Soil in Southwestern Nigeria. Electronic Journal of Geotechnical Engineering (EJGE), vol. 16, p. 1504. 